\title{
PENENTUAN CRITICAL PARTS ALAT BANTU PEMERAS SANTAN MENGGUNAKAN QUALITY FUNCTION DEPLOYMENT FASE KEDUA
}

\author{
Yuswono Hadi ${ }^{1}$, Ahmad Faishal Dahlan² \\ Universitas Ma Chung, Villa Puncak Tidar N 01, Malang \\ E-mail: yuswono.hadi@machung.ac.id
}

\begin{abstract}
Some previous studies used QFD first phase method to obtain customer satisfication of coconut milk squeezer machines, as follows : accelerates extortion process, reduces fatigue, easy to use, optimizes the output, strong construction, rustproof materials, compact design, easy to move, and hygienic. Study developing of the squeezer machine of coconut milk is required to deploy customer satisfication into two parts including specifications and critical parts by using QFD second phase. There are 15 part specifications that obtained by discussing and interviewing with the experts. Then, 4 part specifications such as motor, pressing mechanism, production step, pressing strength, and volume of cylinder were selected as main part to be used for QFD second phase. While, there were 10 critical parts was derived from selected part specification such as pressure strength, hydraulic system, ON/OFF push button, cylinder clamps, the power and voltage that used for the machine, the piston holder material and its diameter.
\end{abstract}

Keywords: Quality Fucntion Deployment second phase, QFD, Part Specification, Critical Part, Coconut Milk Machine

\section{PENDAHULUAN}

Fase desain produk merupakan fase kedua dari Quality Function Deployment (QFD) yang merupakan fase lanjutan dari fase perencanaan produk. Pada fase desain produk, dilakukan penjabaran terhadap atribut persyaratan teknis.

Tabel 1. Atribut Kebutuhan Konsumen untuk Alat Bantu Pemeras Santan

\begin{tabular}{l}
\hline \multicolumn{1}{c}{ Atribut Kebutuhan Konsumen } \\
\hline Mempercepat proses pemerasan \\
Mengurangi tingkat kelelahan \\
Mudah digunakan (tidak rumit) \\
Santan terperas seluruhnya \\
Kapasitas parutan kelapa lebih banyak \\
Rangka kuat \\
Rangka tidak mudah berkarat \\
Alat pemeras tidak memakan banyak \\
tempat \\
Mudah dipindahkan \\
Higienis \\
\hline
\end{tabular}

Dari penelitian sebelumnya [1] didapatkan data mengenai atribut kebutuhan konsumen dari alat bantu pemeras santan, seperti tertera pada Tabel 1. Dari data atribut kebutuhan konsumen tersebut diolah lebih lanjut untuk mendapatkan atribut persyaratan teknis.

Atribut persyaratan teknis didapatkan melalui diskusi dengan dua orang ahli, yakni ahli dalam bidang rancang bangun mesin dan ahli dalam teknik pangan. Penjabaran atribut kebutuhan konsumen tersebut merupakan solusi yang diberikan oleh para ahli terkait dengan alat bantu pemeras santan Tabel 2 . Informasi atribut persyaratan teknis yang tertuang pada Tabel 2, menjadi dasar dilakukanya fase kedua $Q F D$, yakni Product Design yang akan menghasilkan Critical Parts. 
Tabel 2. Atribut Persyaratan Teknis untuk Alat Bantu Pemeras Santan

\begin{tabular}{l}
\hline \multicolumn{1}{c}{ Atribut Persyaratan Teknis } \\
\hline Menggunakan motor penggerak \\
Menggunakan sistem penekanan \\
Volume tabung \\
Desain antropometri \\
Tahapan pemerasan santan \\
Kekuatan tekan \\
Tingkat kepresisian \\
Jumlah lubang tabung santan \\
Jenis material rangka \\
Diameter material rangka \\
Penambahan roda \\
Pengecatan \\
Jenis material komponen pengepresan \\
Mudah dibersihkan \\
Desain modular
\end{tabular}

\section{METODOLOGI PENELITIAN}

Penentuan Part Specification (Fase Desain Produk)

Tahapan pertama dalam melakukan pengolahan data pada fase desain produk yakni menentukan part specification. Data yang digunakan adalah atribut persyaratan teknis pada fase perencanaan produk. Jumlah atribut persyaratan teknis yang digunakan dapat keseluruhan atribut atau hanya sebagian atribut persyaratan teknis [4]. Jika produk tersebut adalah produk baru, maka dapat menggunakan keseluruhan atribut persyaratan teknis [2]. Namun, pemilihan part specification juga dapat dilakukan berdasarkan atribut persyaratan teknis yang mempunyai hubungan kuat dengan tingkat kepentingan pelanggan [3].

\section{Menghitung Derajat Kepentingan Atribut}

Pada tahap ini dilakukan penilaian kepentingan terhadap seluruh atribut kebutuhan konsumen. Dari penilaian tersebut maka akan diketahui atribut mana saja yarig mempunyai tingkat kepentingan cukup tinggi. Penilaian tersebut menggunakan skala Likert yang penilaiannya terbagi atas lima skor $[4,5]$.

Penentuan derajat kepentingan dengan pengelompokan responden yang memberikan nilai sama pada lembar kuisioner, kemudian melakukan penilaian derajat atribut berdasarkan nilai dengan jumlah responden terbanyak [2]. Penentuan derajat kepentingan dapat dihitung menggunakan Persamaan 1 [3].

$$
D K A=\operatorname{modus}\left(N_{1}, N_{2}, N_{3}, N_{4}, N_{5}\right)
$$

Keterangan:

DKA = Derajat Kepentingan Atribut

$\mathrm{N}_{1}$ = Jumlah responden yang memilih nilai 1

$\mathrm{N}_{2}$ = Jumlah responden yang memilih nilai 2

$\mathrm{N}_{3}$ = Jumlah responden yang memilih nilai 3

$\mathrm{N}_{4}$ = Jumlah responden yang memilih nilai 4

$\mathrm{N}_{5} \quad=$ Jumlah responden yang memilih nilai 5

\section{Menghitung Bobot Absolut Persyaratan Teknis}

Langkah selanjutnya yakni menghitung bobot absolut persyaratan teknis dengan menggunakan Persamaan 2 [3].

$$
a_{j}=\sum_{i=1}^{n} R_{i j} C_{i}
$$

Keterangan:

$a_{j}=$ baris bobot absolut persyaratan teknis

$R_{i j}=$ nilai bobot pada relationships

= derajat kepentingan dari atribut kebutuhan konsumen ke-i $(\mathrm{i}=1, \ldots ., \mathrm{m})$

$\mathrm{m}=$ nomor persyaratan teknis

$\mathrm{n}=$ nomor atribut customer need

\section{Menghitung Bobot Relatif Persyaratan Teknis}

Selanjutnya menentukan bobot relatif persyaratan teknis menggunakan Persamaan 3.

$$
b_{j}=\sum_{i=1}^{n} R_{i j} D_{i}
$$

Keterangan:

$a_{j}=$ baris bobot absolut persyaratan teknis

$R_{i j}=$ nilai bobot pada relationships

= nilai bobot absolut (raw weight) kebutuhan

konsumen dari atribut ke-i $(\mathrm{i}=1, \ldots, \mathrm{m})$

$\mathrm{m}=$ nomor persyaratan teknis

$\mathrm{n}$ = nomor atribut customer need

Menghitung Tingkat Kepentingan dan Bobot Relatif Part Specification 
Langkah selanjutnya yakni memindahkan atribut persyaratan teknis pada QFD fase pertama ke bagian kiri rumah QFD fase dua. Setelah itu ditentukan tingkat kepentingan atribut part specification [3] yang dihitung menggunakan Persamaan 4.

$$
T K_{s p}=\frac{\text { Bobot Relatif Persyaratan Teknis }}{\sum \text { Bobot Relatif Persyaratan Teknis }}
$$

\section{Menentukan Primary Crtical Part dan Secondary Critical Part}

Pada tahap ini dilakukan penentuan critical part dengan cara diskusi bersama ahli. Critical part sendiri dibagi menjadi dua macam, yakni primary critical part dan secondary critical part. Primary critical part merupakan atribut yang bersifat umum namun masih sesuai dengan part specification, sedangkan secondary critical part merupakan penjabaran dari primary critical part [2]. Hasil diskusi dengan ahli akan menghasilkan atribut critical part yang mana jumlahnya mungkin berbeda dari atribut part specification.

\section{Membuat Matriks Korelasi dan Matriks Trade-Offs}

Tahap ini akan menghubungkan atribut part specification dengan atribut critical part. Hubungan yang terjadi tidak selamanya $1: 1$ tapi bisa lebih dari itu. Bisa juga tidak tidak terjadi hubungan sama sekali. Penilaian pada matriks tersebut sama dengan tahap relationships pada fase desain yakni dengan menggunakan simbol, yang mana simbol tersebut mempunyai nilai tersendiri.

Setelah itu, dilakukan pengisian matriks technical correlation yang menghubungkan tiap-tiap atribut critical part. Tujuannya untuk mengetahui keterkaitan antar atribut critical part yang nantinya juga berpengaruh pada penentuan bobot prioritas.

\section{Perhitungan Bobot Kepentingan dan Prioritas \\ Bobot kepentingan dapat dihitung menggunakan Persamaan 5 [3].}

$B K=\sum$ Bobot relatif part specification $\times$

nilai matriks korelasi

Setelah itu ditentukan nilai prioritasnya berdasarkan bobot kepentingan tertinggi.

\section{Membuat Matriks Design Product}

Hasil semua perhitungan yang menjadi komponen penyusunan matriks design product akan dikumpulkan menjadi satu. Hal tersebut dilakukan untuk mempermudah pembacaan data penelitian.

\section{Analisis Data}

Pada tahap ini dilakukan analisis mengenai penelitian yang telah dilakukan dari fase desain sampai dengan fase detail. Tahap ini mencoba menganalisis perumusan masalah yang telah disebutkan di awal.

\section{HASIL DAN PEMBAHASAN \\ Part Spesification}

Part specification merupakan dasar dalam melakukan QFD fase desain produk seperti pada Tabel 3. Atribut part specification didapatkan dari atribut persyaratan teknis pada QFD fase perencanaan produk (HOQ).

Tabel 3. Part Specification

\begin{tabular}{cl}
\hline No. & \multicolumn{1}{c}{ Part Specification } \\
\hline 1 & Menggunakana motor penggerak \\
2 & Mekanisme penekanan \\
3 & Tahapan proses pemerasan \\
4 & Kekuatan tekan
\end{tabular}

Terdapat empat atribut persyaratan teknis yang akan digunakan sebagai part specification, yakni atribut menggunakan motor penggerak, atribut mekanisme penekanan, atribut tahapan proses pemerasan dan atribut kekuatan tekan.

\section{Menghitung Derajat Kepentingan Atribut}

Metode ini mengelompokkan nilai yang muncul untuk tiap atribut kebutuhan konsumen. Hasil penentuan derajat kepentingan akan dijadikan acuan dalam perhitungan bobot absolut persyaratan teknik. Tabel 4 merupakan hasil perhitungan derajat kepentingan atribut. 
Tabel 4. Tingkat Kepentingan Atribut

\begin{tabular}{clc}
\hline No. & $\begin{array}{l}\text { Atribut Kebutuhan } \\
\text { Konsumen }\end{array}$ & $\begin{array}{c}\text { Derajat } \\
\text { Kepentingan }\end{array}$ \\
\hline 1 & $\begin{array}{l}\text { Mempercepat } \\
\text { proses pemerasan }\end{array}$ & 5 \\
2 & $\begin{array}{l}\text { Mengurangi } \\
\text { tingkat kelelahan }\end{array}$ & 5 \\
3 & $\begin{array}{l}\text { Mudah digunakan } \\
\text { (tidak rumit) }\end{array}$ & 5 \\
4 & $\begin{array}{l}\text { Santan terperas } \\
\text { seluruhnya }\end{array}$ & 5 \\
5 & $\begin{array}{l}\text { Kapasitas parutan } \\
\text { kelapa lebih } \\
\text { banyak }\end{array}$ & 3 \\
6 & $\begin{array}{l}\text { Rangka kuat } \\
\text { Rangka tidak } \\
\text { mudah karat }\end{array}$ & 5 \\
8 & $\begin{array}{l}\text { Higienis } \\
\text { Alat pemeras tidak } \\
\text { memakan banyak } \\
\text { tempat } \\
10\end{array}$ & $\begin{array}{l}\text { Mudah } \\
\text { dipindahkan }\end{array}$ \\
\hline
\end{tabular}

Menghitung Bobot Absolut Persyaratan Teknis

Perhitungan bobot absolut digunakan untuk menentukan bobot dari masing-masing atribut persyaratan teknis yang didasarkan pada nilai hubungan atribut persyaratan teknis dan derajat kepentingan seperti pada Tabel 5 . Perhitungan bobot absolut juga sudah dilakukan pada fase perencanaan produk, namun dilakukan lagi sesuai dengan metode yang digunakan.

\section{Menghitung Bobot Relatif Persyaratan Teknis}

Bobot relatif adalah bobot dari atribut persyaratan teknis terhadap atribut kebutuhan konsumen khususnya yang mempunyai hubungan seperti pada Tabel 6. Nilainya didapat melalui perhitungan antara nilai korelasi dikalikan dengan raw weight pada HOQ.

Tabel 5. Hasil Perhitungan Bobot Absolut Persyaratan Teknis

\begin{tabular}{clrrrr}
\hline No. & $\begin{array}{c}\text { Atribut Persyaratan } \\
\text { Teknis }\end{array}$ & $\begin{array}{c}\text { Bobot } \\
\text { Relatif } \\
\text { Teknik }\end{array}$ & $\begin{array}{c}\text { Tingkat } \\
\text { Kepentingan }\end{array}$ & $\begin{array}{c}\text { Bobot Relatif } \\
\text { Part } \\
\text { Specificatiion }\end{array}$ & Persentase \\
\hline 1 & $\begin{array}{l}\text { Menggunakan motor } \\
\text { penggerak }\end{array}$ & 344,72 & 0,15 & 0,25 & $25 \%$ \\
2 & $\begin{array}{l}\text { Mekanisme } \\
\text { penekanan }\end{array}$ & 461,31 & 0,20 & 0,34 & $34 \%$ \\
3 & $\begin{array}{l}\text { Tahapan pemerasan } \\
\text { santan }\end{array}$ & 298,82 & 0,13 & 0,22 & $22 \%$ \\
4 & Kekuatan tekan & 258,81 & 0,11 & 0,19 & $19 \%$ \\
$\quad$ Total & $\mathbf{1 3 6 3 , 8 1}$ & - & - & - \\
\hline
\end{tabular}


Tabel 6. Hasil Perhitungan Bobot Relatif Tabel 7. Hasil Perhitungan Tingkat Persyaratan Teknis

\begin{tabular}{|c|c|c|c|}
\hline No & $\begin{array}{c}\text { Atribut } \\
\text { Persyaratan } \\
\text { Teknis }\end{array}$ & $\begin{array}{l}\text { Bobot } \\
\text { Relatif }\end{array}$ & Target \\
\hline 1 & $\begin{array}{l}\text { Menggunakan } \\
\text { motor } \\
\text { penggerak }\end{array}$ & 344,72 & 2 \\
\hline 2 & $\begin{array}{l}\text { Mekanisme } \\
\text { penekanan }\end{array}$ & 461,31 & 1 \\
\hline 3 & $\begin{array}{l}\text { Diameter } \\
\text { tabung }\end{array}$ & 136,62 & 7 \\
\hline 4 & $\begin{array}{l}\text { Desain } \\
\text { ergonomis }\end{array}$ & 150,92 & 5 \\
\hline 5 & $\begin{array}{l}\text { Tahapan } \\
\text { pemerasan } \\
\text { santan }\end{array}$ & 298,82 & 3 \\
\hline 6 & $\begin{array}{l}\text { Kekuatan } \\
\text { tekan }\end{array}$ & 258,95 & 4 \\
\hline 7 & $\begin{array}{l}\text { Tingkat } \\
\text { kepresisian } \\
\text { Jumlah }\end{array}$ & 148,74 & 6 \\
\hline 8 & $\begin{array}{l}\text { lubang } \\
\text { tabung santan }\end{array}$ & 148,74 & 6 \\
\hline 9 & $\begin{array}{l}\text { Jenis material } \\
\text { rangka } \\
\text { Diameter }\end{array}$ & 100,58 & 8 \\
\hline 10 & & 45,90 & 12 \\
\hline 11 & $\begin{array}{l}\text { Pemberian } \\
\text { roda }\end{array}$ & 66,76 & 9 \\
\hline 12 & Pengecatan & 54,68 & 11 \\
\hline 13 & $\begin{array}{l}\text { Jenis material } \\
\text { komponen } \\
\text { pengepresan }\end{array}$ & 60,92 & 10 \\
\hline 14 & $\begin{array}{l}\text { Mudah } \\
\text { dibersihkan }\end{array}$ & 60,92 & 10 \\
\hline 15 & $\begin{array}{l}\text { Desain } \\
\text { Modular }\end{array}$ & 20,31 & 13 \\
\hline
\end{tabular}

Kepentingan dan Bobot Relatif Part Specification

\begin{tabular}{llc}
\hline No. & $\begin{array}{l}\text { Atribut Persyaratan } \\
\text { Teknis }\end{array}$ & $\begin{array}{l}\text { Bobot } \\
\text { Absolut }\end{array}$ \\
\hline 1 & Menggunakan motor & 171 \\
2 & $\begin{array}{l}\text { penggerak } \\
\text { Mekanisme penekanan }\end{array}$ & 216 \\
3 & Diameter tabung & 72 \\
4 & Desain ergonomis & 81 \\
5 & Tahapan pemerasan & 135 \\
6 & santan Kekuatan tekan & 126 \\
7 & Tingkat kepresisian & 60 \\
8 & Jumlah lubang tabung & 60 \\
9 & santan Jenis material rangka & 81 \\
10 & Diameter material rangka & 36 \\
11 & Pemberian roda & 36 \\
12 & Pengecatan & 45 \\
13 & Jenis material komponen & 45 \\
14 & pengepresan & Mudah dibersinkan \\
15 & Desain Modular & 45 \\
\hline
\end{tabular}

Pada dasarnya persyaratan teknis dengan part specification adalah sama. Perbedaannya terletak pada fungsinya, persyaratan teknis didapatkan dari penjabaran atribut kebutuhan konsumen sedangkan part specification merupakan pondasi dalam menentukan critical part pada QFD fase desain produk. Terdapat empat atribut persyaratan teknis yang akan dijadika part specification, yakni atribut menggunakan

Menghitung Tingkat Kepentingan dan motor penggerak, atribut mekanisme Bobot Relatif Part Specification

Pada tahap ini dilakukan perhitungan tingkat kepentingan dan bobot relatif dari part specificaton yang disajikan pada Tabel 7 . penekanan, atribut tahapan pemerasan, dan atribut kekuatan tekan.Berikut ini merupakan contoh perhitungan tingkat kepentingan dan bobot relatif untuk part specification.

\section{Menentukan Primary Critical dan Secondary Critical Part \\ Pada tahap ini akan dilakukan analisis critical part terhadap part specificatiion produk}


yang nantinya akan dihasilkan. Critical part dibagi atas dua macam, yakni primer dan sekunder. Primary critical masih bersifat umum sedangkan secondary critical lebih spesifik atau penjabaran primary critical. Data critical part didapatkan melalui diskusi dan wawancara dengan ahli rancang bangun mesin. Primary critical terbagi atas dua kategori, yakni sistem penekanan dan sistem penggerak. Tabel 8 menyajikan identifikasi dari masing-masing primary critical.

Tabel 8. Primary dan Secondary Critical Part

$\begin{array}{lc}\text { Sistem } & \text { Sistem hidrolis } \\ \text { penekanan } & \text { Momen penekanan } \\ & \text { Beban penekanan }\end{array}$

Diameter matras piston

Material matrass piston

Penjepit tabung santan

Motor AC

Daya motor

Tegangan motor

Saklar push button

\section{Membuat Matriks Product Design}

Langkah terakhir pada QFD fase desain produk adalah membuat matriks product design. Perhitungan pada tahap sebelumnya akan dikumpulkan jadi satu pada matriks ini. Matriks product design mesin pemeras santan dapat dilihat pada Gambar 1.

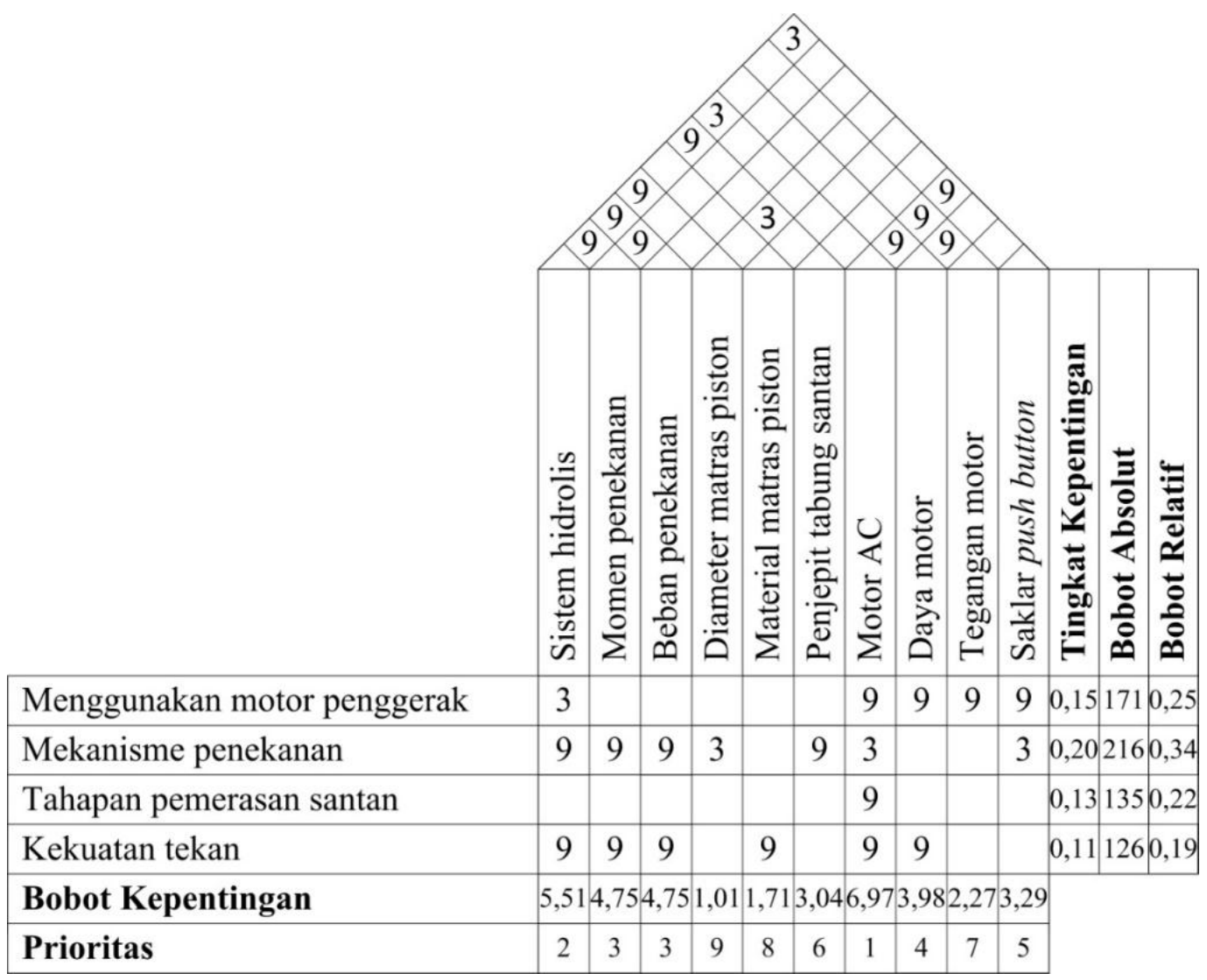

Gambar 1. Matriks House of Quality (HoQ) untuk QFD fase Kedua 


\section{KESIMPULAN}

Terdapat 15 atribut persyaratan teknis yang didapatkan melalui diskusi dan wawancara dengan dua orang ahli. Atribut persyaratan teknis tersebut merupakan penjabaran dari atribut kebutuhan konsumen. Dari 15 atribut persyaratan teknis tersebut terdapat empat atribut yang dipilih sebagai landasan dalam QFD fase desain, atribut tersebut yakni menggunakan motor penggerak, mekanisme penekanan, tahapan pemerasan santan, dan kekuatan tekan.

Terdapat 10 atribut critical part sekunder yang merupakan penjabaran dari part specification. Atribut momen penekanan dan beban penekanan berada pada urutan pertama. Atribut sistem hidrolis berada pada urutan ke dua, daya motor pada urutan ke tiga, saklar push button pada urutan ke empat, daya motor pada urutan ke lima, penjepit tabung santan pada urutan ke enam, tegangan motor pada urutan ke tujuh, dan diameter serta material matras piston pada urutan ke delapan.

\section{DAFTAR PUSTAKA}

[1] Ahmad Faishal Dahlan, 2016, Penentuan persyaratan teknik dan critical part alat bantu pemeras santan, menggunakan QFD Fase Pertama dan Kedua, Skripsi, Fakultas Sains dan Teknologi, Universitas Ma Chung, Malang

[2] Bazarado, M., 2014, Perancangan Atribut Produk Olahan Wortel Menggunakan Metode Quality Function Deployment (QFD) Tahap Kedua, Skirpsi, Teknik Industri, Universitas Ma Chung, Malang.

[3] Sriwahyuni, W., 2006, Analisis Diversifikasi Produk Minuman Pada CV Fauzi Kabupaten Bekasi Propinsi Jawa Barat Menggunakan Metode Quality Function Deployment, Skirpsi, Ekstensi Manajemen Agribisnis, Institut Pertanian Bogor, Bogor.

[4] Halim, Veronica., Yurida Ekawati. 2014. Perencanaan Produk Olahan Wortel Menggunakan Metode Quality Function Deployment (QFD). Jurnal Symbol. Vol. 1 No. 1. pp 57-67. ISSN : 9772356441035. Universitas Ma Chung. Malang

[5] Rahman, Abdul., Heri Supomo. 2012. Analisa Kepuasan Pelanggan pada Pekerjaan Reparasi Kapal dengan Metode Quality Function Deployment (QFD). Jurnal Teknik ITS. Vol. 1. No. 1. pp 297302. ISSN : 2301-9271. 